\title{
Chemical Constituents from Chirita longgangensis var. hongyao with Inhibitory Activity against Porcine Respiratory and Reproductive Syndrome Virus
}

\author{
Yao Su, ${ }^{a, b}$ Jun-Long Bi, ${ }^{c}$ Yue-Hu Wang, ${ }^{a}$ Ying Tan, ${ }^{a}$ Jun Yang, ${ }^{a, b}$ Hong-Xin Liu, ${ }^{a}$ Wei Gu, ${ }^{a}$ \\ Ge-Fen Yin*,c and Chun-Lin Long*,a,d
}

${ }^{a}$ Key Laboratory of Economic Plants and Biotechnology, Kunming Institute of Botany, Chinese Academy of Sciences, Kunming 650201, P. R. China

${ }^{b}$ School of Agronomy and Biotechnology and ${ }^{c}$ College of Animal Science and Technology, Yunnan Agricultural University, Kunming 650201, P. R. China

${ }^{d}$ College of Life and Environmental Sciences, Minzu University of China, Beijing 100081, P. R. China

\begin{abstract}
Dois novos quinenóides chiritalona $\mathrm{A}$ and $\mathrm{B}$, e uma nova neolignina 7'E-4,9-dihidroxi3,3',5'-trimethoxi-8,4'-oxineolign-7'-en-9'-al, além dos conhecidos (-)-8-hidroxi- $\alpha$-dunniona, digiferruginol, 2,5-dimetoxi-1,4-benzoquinona e hederagenina, foram isolados do caule de Chirita longgangensis var. hongyao. As estruturas dos novos compostos foram elucidadas por análise detalhada de dados obtidos pela técnicas de NMR (ressonância magnética nuclear) e MS (espectrometria de massas), e a configuração absoluta de chiritalona A foi determinada por análise de difração de raios X de monocristal utilizando o parâmetro Flack. A atividade inibitória dos compostos com relação ao vírus da síndrome respiratória e reprodutiva suína (PRRSV) foi medida pelo método do efeito citopático (CPE). Digiferruginol e hederagenina apresentaram efeito fraco com relação ao PRRSV com valor $\mathrm{IC}_{50}$ de $80,5 \pm 16,9 \mu \mathrm{mol} \mathrm{L}^{-1}(\mathrm{SI}=19,9)$ e $43,2 \pm 7,4 \mu \mathrm{mol} \mathrm{L}^{-1}$ $(\mathrm{SI}=13,1)$, respectivamente.
\end{abstract}

Two new quinonoids chiritalone $\mathrm{A}$ and $\mathrm{B}$, and a new neolignan 7'E-4,9-dihydroxy3,3',5'-trimethoxy-8,4'-oxyneolign-7'-en-9'-al, along with known (-)-8-hydroxy- $\alpha$-dunnione, digiferruginol, 2,5-dimethoxy-1,4-benzoquinone and hederagenin, were isolated from the stems of Chirita longgangensis var. hongyao. The structures of the new compounds were elucidated by detailed analysis from NMR (nuclear magnetic resonance) and MS (mass spectrometry) data, and the absolute configuration of chiritalone A was determined by single crystal X-ray diffraction analysis using the Flack parameter. The inhibitory activity of compounds against porcine respiratory and reproductive syndrome virus (PRRSV) was measured by the cytopathic effect (CPE) method. Digiferruginol and hederagenin showed weak effect on PRRSV with an $\mathrm{IC}_{50}$ value of $80.5 \pm 16.9 \mu \mathrm{mol} \mathrm{L}-1(\mathrm{SI}=19.9)$ and $43.2 \pm 7.4 \mu \mathrm{mol} \mathrm{L}-1 \quad(\mathrm{SI}=13.1)$, respectively.

Keywords: Gesneriaceae; Chirita longgangensis var. hongyao, quinines, porcine reproductive and respiratory syndrome virus

\section{Introduction}

Porcine reproductive and respiratory syndrome (PRRS), caused by porcine reproductive and respiratory syndrome virus (PRRSV), is characterized by respiratory disorders in young pigs and reproductive failure in sows. It is widespread in most major pig-producing areas throughout the world and is one of the most important causes of economic loss to the

*e-mail: long@mail.kib.ac.cn; yingefen383@sohu.com swine industry. In China, in 2006 only, PRRS spread to more than 10 provinces (or autonomous regions) and affected over 2,000,000 pigs with about 400,000 fatal cases. ${ }^{1}$ Although previous studies provided a basis for development of pharmacological agents to inhibit PRRSV replication, so far there are no effective drugs to overcome this problem, ${ }^{2}$ and many vaccine strategies developed to control the disease are not yet completely successful. ${ }^{3,4}$

Quinones are a widespread group of oxygen-substituted aromatic compounds, and some of them are considered 
as inhibitory agents against both RNA and DNA virus. ${ }^{5}$ Plants of Gesneriaceae such as Streptocarpus dunnii Mast., Chirita eburnea Hance, Sinningia aggregata (Ker-Gawl.) Wiehler, and Didymocarpus hedyotideus Chun. are rich in quinones. ${ }^{6-10}$ Chirita longgangensis var. hongyao, a species of Gesneriaceae, is distributed in Guangxi of China, ${ }^{11}$ and is used in the treatment of bone fractures, wounds and pains. ${ }^{12}$ The chemical constituents of Chirita are mainly phenylethanoid glycosides, flavonoids and quinones. ${ }^{13-17}$ Our group conducted a phytochemical research on the stems of the plant, which led to the isolation of seven compounds (1-7) including two new quinones ( $\mathbf{1}$ and $\mathbf{2}$ ) and the new neolignan (3) (Figure 1). All of the isolates were evaluated for their inhibitory activity against PRRSV. The structure elucidation of the new constituents and the bioassay results are reported.

\section{Results and Discussion}

Chiritalone A (1) was obtained as colorless crystals. The molecular formula $\mathrm{C}_{15} \mathrm{H}_{16} \mathrm{O}_{6}$, indicating eight degrees of unsaturation, was determined from the HRESIMS (highresolution electrospray ionization mass spectrometry) quasi-molecular ion $[\mathrm{M}-\mathrm{H}]^{-}$at $\mathrm{m} / \mathrm{z}, 291.0865$ (calcd. 291.0868). The IR spectrum revealed absorption bands for free hydroxy $\left(3521 \mathrm{~cm}^{-1}\right)$, chelated $\mathrm{OH}\left(3381 \mathrm{~cm}^{-1}\right)$ and CO groups $\left(1685 \mathrm{~cm}^{-1}\right)$. The ${ }^{1} \mathrm{H}$ and ${ }^{13} \mathrm{C}$ nuclear magnetic resonance (NMR) spectra of $\mathbf{1}$ (Table 1) showed signals for two conjugated $\mathrm{CO}$ groups $\left(\delta_{\mathrm{C}} 196.5\right.$ and $\left.195.8 \mathrm{ppm}\right)$, a trisubstituted $\mathrm{Ph}$ ring $\left[\delta_{\mathrm{H}} 7.66 \mathrm{ppm}(\mathrm{dd}, J 8.3,7.6 \mathrm{~Hz})\right.$, $7.59 \mathrm{ppm}(\mathrm{dd}, J 7.6,1.2 \mathrm{~Hz})$ and $7.30 \mathrm{ppm}(\mathrm{d}, J$ 8.3, $1.2 \mathrm{~Hz}$ )], three $\mathrm{sp}^{3}$ quaternary $\mathrm{C}$-atoms including two $O$-bearing ones $\left(\delta_{\mathrm{C}} 99.9,86.9\right.$ and $\left.51.2 \mathrm{ppm}\right)$, one $O$-bearing $\mathrm{CH}$ group $\left(\delta_{\mathrm{C}} 82.0 \mathrm{ppm}\right)$, and three Me groups $\left[\delta_{\mathrm{H}} 1.08 \mathrm{ppm}\right.$ (d, $J 6.4 \mathrm{~Hz}), 0.96 \mathrm{ppm}(\mathrm{s})$, and $0.57 \mathrm{ppm}(\mathrm{s})]$. Comparison
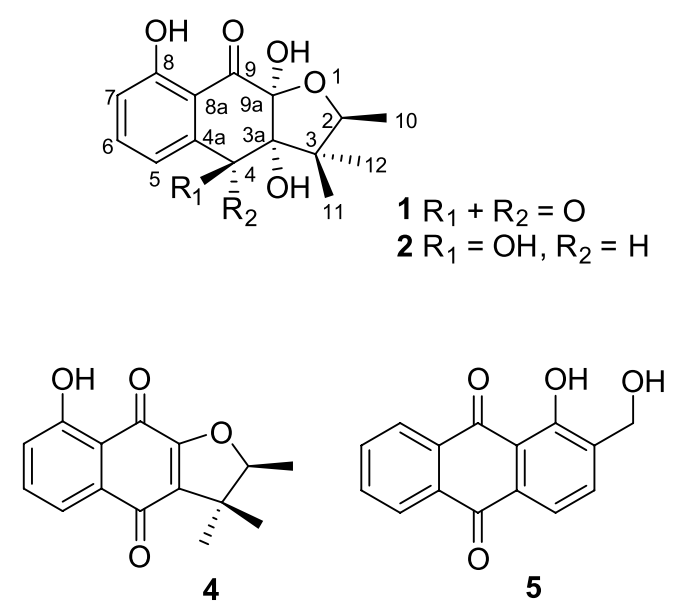

of NMR data of $\mathbf{1}$ with those of the known quinone (-)-8-hydroxy- $\alpha$-dunnione $(\mathbf{4})^{8}$ revealed that compound $\mathbf{1}$ possessed signals for the enone in $\mathbf{4}$, thus suggesting that the C-3a and C-9a in $\mathbf{1}$ might be both hydroxylated. Most of the ${ }^{13} \mathrm{C}$ NMR signals for $\mathbf{1}$ were assigned by heteronuclear multiple bond correlation (HMBCs) (Figure 2).

To elucidate the absolute configuration, the crystals of $\mathbf{1}$ was obtained from a mixture solvent of petroleum ether/ $\mathrm{CHCl}_{3}(2: 1)$, and its integrated structure and absolute configuration were finally determined by the single-crystal $\mathrm{X}$-ray diffraction study using graphite-monochromated $\mathrm{Cu} \mathrm{K} \mathrm{K}_{\alpha}$ radiation in light of the Flack parameter of 0.1(2) (Figure 3). Thus, 1 was elucidated as $(2 S, 3 \mathrm{a} R, 9 \mathrm{a} S)$ 3a,8,9a-trihydroxy-2,3,3-trimethyl-2,3,3a,9atetrahydronaphtho[2,3-b]furan-4,9-dione, and named as chiritalone A.

Compound 2 was isolated as a colorless amorphous solid. Its molecular formula was assigned as $\mathrm{C}_{15} \mathrm{H}_{18} \mathrm{O}_{6}$ from the HRESIMS quasimolecular ion $[\mathrm{M}-\mathrm{H}]^{-}$at $\mathrm{m} / \mathrm{z}$ 293.1024 space (calcd. 293.1025), which indicated seven degrees of unsaturation. The IR spectrum of 2 showed absorption bands for $\mathrm{OH}\left(3441 \mathrm{~cm}^{-1}\right)$ and $\mathrm{CO}\left(1631 \mathrm{~cm}^{-1}\right)$ groups. The ${ }^{1} \mathrm{H}$ and ${ }^{13} \mathrm{C}$ NMR spectra of 2 (Table 1) showed signals for one conjugated CO group $\left(\delta_{\mathrm{C}} 198.2 \mathrm{ppm}\right)$, a trisubstituted $\mathrm{Ph}$ ring $\left[\delta_{\mathrm{H}} 7.62 \mathrm{ppm}(\mathrm{t}, J 8.0 \mathrm{~Hz}), 7.20 \mathrm{ppm}\right.$ $(\mathrm{d}, J 8.0 \mathrm{~Hz})$ and $6.85 \mathrm{ppm}(\mathrm{d}, J 8.0 \mathrm{~Hz})]$, three $\mathrm{sp}^{3}$ quaternary $\mathrm{C}$-atoms including two $O$-bearing ones $\left(\delta_{\mathrm{C}} 99.7\right.$, 83.1 and $48.6 \mathrm{ppm})$, two $O$-bearing $\mathrm{CH}$ groups $\left(\delta_{\mathrm{C}} 80.4\right.$ and $72.4 \mathrm{ppm}$ ) and three Me groups $\left[\delta_{\mathrm{H}} 1.06 \mathrm{ppm}(\mathrm{s}), 0.86 \mathrm{ppm}\right.$ $(\mathrm{d}, J 6.4 \mathrm{~Hz}$ ), and $0.35 \mathrm{ppm}(\mathrm{s})]$. These data were very similar to those of $\mathbf{1}$ except that the signal for one ketone group in $\mathbf{1}$ was replaced by the signal for the $O$-bearing $\mathrm{CH}$ group $\left(\delta_{\mathrm{C}} 72.4 \mathrm{ppm}\right)$ in $\mathbf{2}$. This implied that one of the ketone groups was reduced to an $O$-bearing $\mathrm{CH}$ group in $\mathbf{2}$. The group was located at C-4 by the HMBCs correlations
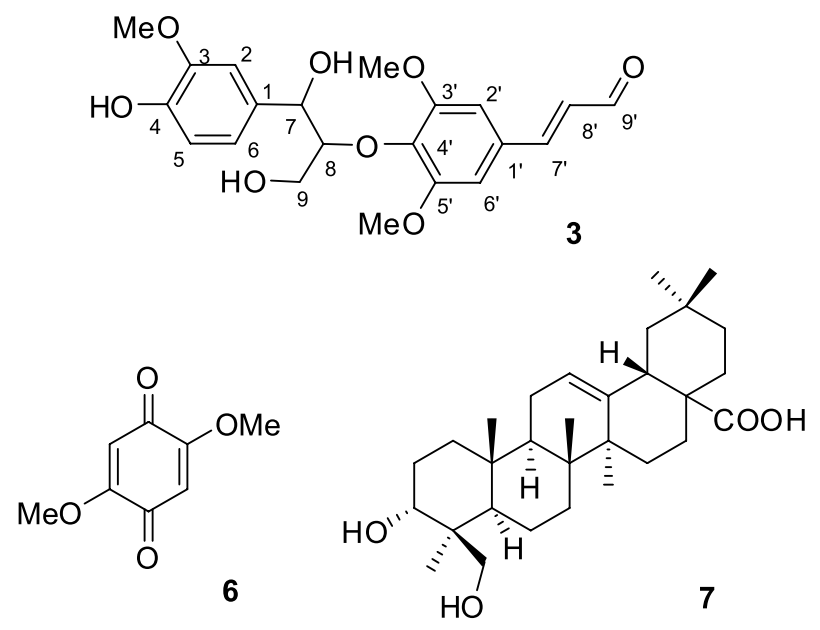

Figure 1. Chemical structures of compounds 1-7. 
Table 1. NMR data of compounds $\mathbf{1}$ and $\mathbf{2}(\delta$ in ppm, $J$ in $\mathrm{Hz}$ )

\begin{tabular}{|c|c|c|c|c|c|c|}
\hline \multirow{2}{*}{ Position } & \multicolumn{2}{|c|}{ Compound 1} & \multicolumn{4}{|c|}{ Compound 2} \\
\hline & $\delta_{\mathrm{H}}{ }^{\mathrm{a}}$ & $\delta_{\mathrm{C}}^{\mathrm{b}}$ & $\delta_{\mathrm{H}}^{\mathrm{c}}$ & $\delta_{\mathrm{C}}^{\mathrm{d}}$ & $\delta_{\mathrm{H}}^{\mathrm{e}}$ & $\delta_{\mathrm{C}}{ }^{\mathrm{f}}$ \\
\hline 2 & $4.26(\mathrm{q}, 6.4)$ & 82.0 & $4.07(\mathrm{q}, 6.4)$ & 80.4 & $4.26(\mathrm{q}, 6.4)$ & 82.6 \\
\hline 3 & & 51.2 & & 48.6 & & 50.3 \\
\hline $3 a$ & & 86.9 & & 83.1 & & 84.5 \\
\hline 4 & & 196.5 & $4.79(\mathrm{~d}, 4.7)$ & 72.4 & 4.95 (br. s) & 74.6 \\
\hline $4 a$ & & 134.5 & & 147.1 & & 147.6 \\
\hline 5 & $7.59(\mathrm{dd}, 7.6,1.2)$ & 119.1 & $6.85(\mathrm{~d}, 8.0)$ & 115.5 & $7.26(\mathrm{~d}, 8.0)$ & 116.4 \\
\hline 6 & $7.66(\mathrm{dd}, 8.3,7.6)$ & 138.1 & $7.62(\mathrm{t}, 8.0)$ & 138.1 & $7.61(\mathrm{t}, 8.0)$ & 139.2 \\
\hline 7 & $7.30(\mathrm{dd}, 8.3,1.2)$ & 126.0 & $7.20(\mathrm{~d}, 8.0)$ & 115.6 & $6.87(\mathrm{~d}, 8.0)$ & 116.8 \\
\hline 8 & & 163.8 & & 162.1 & & 164.4 \\
\hline $8 \mathrm{a}$ & & 116.2 & & 113.3 & & 114.6 \\
\hline 9 & & 195.8 & & 198.2 & & 199.3 \\
\hline $9 \mathrm{a}$ & & 99.9 & & 99.7 & & 100.9 \\
\hline 10 & $1.08(\mathrm{~d}, 6.4,3 \mathrm{H})$ & 13.6 & $0.86(\mathrm{~d}, 6.4,3 \mathrm{H})$ & 13.2 & $0.99(\mathrm{~d}, 6.4,3 \mathrm{H})$ & 13.3 \\
\hline 11 & $0.57(\mathrm{~s}, 3 \mathrm{H})$ & 19.5 & $0.35(\mathrm{~s}, 3 \mathrm{H})$ & 18.9 & $0.49(\mathrm{~s}, 3 \mathrm{H})$ & 19.4 \\
\hline 12 & $0.96(\mathrm{~s}, 3 \mathrm{H})$ & 17.8 & $1.06(\mathrm{~s}, 3 \mathrm{H})$ & 20.7 & $1.19(\mathrm{~s}, 3 \mathrm{H})$ & 20.9 \\
\hline $4-\mathrm{OH}$ & & & $6.23(\mathrm{~d}, 4.7)$ & & & \\
\hline $8-\mathrm{OH}$ & $12.07(\mathrm{~s})$ & & 12.00 (br. s) & & & \\
\hline $3 \mathrm{a}-\mathrm{OH}$ & & & 5.39 (br. s) & & & \\
\hline
\end{tabular}

${ }^{\mathrm{a}}{ }^{1} \mathrm{H}$ NMR of 1 recorded in $\mathrm{CDCl}_{3}$ at $400 \mathrm{MHz} ;{ }^{\mathrm{b}}{ }^{13} \mathrm{C} \mathrm{NMR}$ of 1 recorded in $\mathrm{CDCl}_{3}$ at $100 \mathrm{MHz} ;{ }^{\mathrm{c} 1} \mathrm{H}$ NMR of 2 recorded in DMSO- $d_{6}$ at $600 \mathrm{MHz} ;{ }^{\mathrm{d} 13} \mathrm{C} \mathrm{NMR}$ of 2 recorded in DMSO- $d_{6}$ at $150 \mathrm{MHz} ;{ }^{\mathrm{e}} \mathrm{H}$ NMR of 2 recorded in $\mathrm{CD}_{3} \mathrm{OD}$ at $100 \mathrm{MHz} ;{ }^{\mathrm{f}}{ }^{13} \mathrm{C}$ NMR of 2 recorded in $\mathrm{CD}_{3} \mathrm{OD}$ at $100 \mathrm{MHz}$.
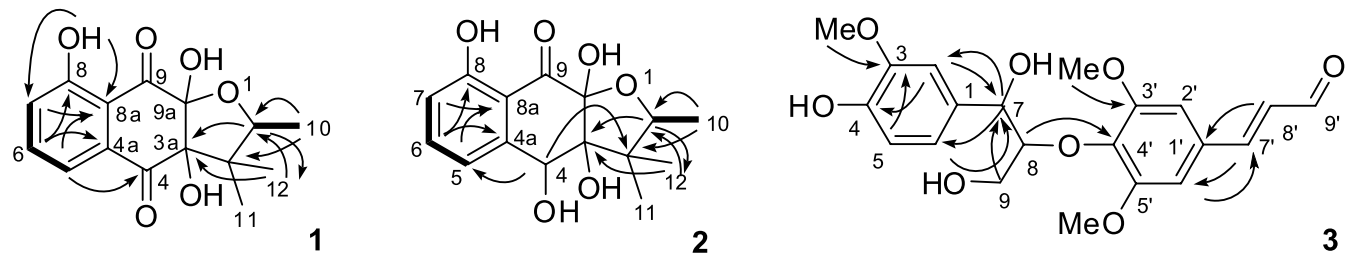

Figure 2. ${ }^{1} \mathrm{H}-{ }^{1} \mathrm{H}$ COSY (bold) and key HMBC $(\mathrm{H} \rightarrow \mathrm{C})$ correlations of compounds 1-3.

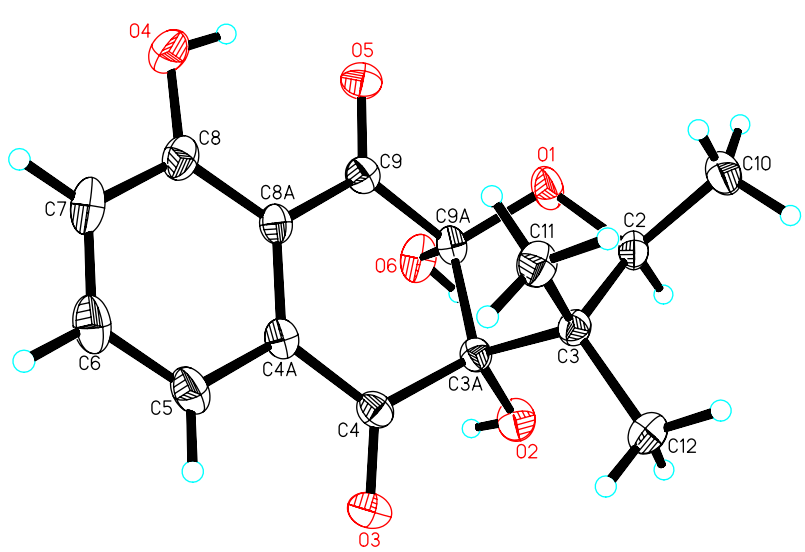

Figure 3. ORTEP drawing of the asymmetric unit of compound $\mathbf{1}$.

from $\mathrm{H}-4$ to $\mathrm{C}-3$ and $\mathrm{C}-5$, and $4-\mathrm{OH}$ to $\mathrm{C}-4 \mathrm{a}$ (Figure 2). Accordingly, the planar structure of $\mathbf{2}$ was elucidated as 3a,4,8,9a-tetrahydroxy-2,3,3-trimethyl-2,3,3a,4,9apentahydronaphtho[2,3-b]furan-9-one.

The relative configuration of $\mathbf{2}$ was determined by the rotating-frame Overhauser spectroscopy (ROESY) spectrum of 2 (Figure 4). Key ROESY correlations $\mathrm{H}-2 / 3 \mathrm{a}-\mathrm{OH}, \mathrm{H}-2 / 12-\mathrm{Me}$ and $\mathrm{H}-4 / 3 \mathrm{a}-\mathrm{OH}$ suggested these protons to be cofacial and were arbitrarily assigned in $\alpha$-orientation. Therefore, $\mathbf{2}$ was determined as rel-(2R,3a $S, 4 R, 9 \mathrm{a} R)-3 \mathrm{a}, 4,8,9 \mathrm{a}$-tetrahydroxy-2,3,3trimethyl-2,3, 3a,4,9a-pentahydronaphtho[2,3- $b$ ]furan9-one and given the trivial name chiritalone $\mathrm{B}$.

Compound $\mathbf{3}$ was isolated as an oil, and its molecular formula established as $\mathrm{C}_{21} \mathrm{H}_{24} \mathrm{O}_{8}$ from the HRESIMS quasi-molecular ion $[\mathrm{M}-\mathrm{H}]^{-}$at $\mathrm{m} / \mathrm{z} 403.1390$ (calcd. 403.1392). The IR absorption bands of $\mathbf{3}$ were indicative of $\mathrm{OH}$ presence of $\mathrm{OH}\left(3440 \mathrm{~cm}^{-1}\right), \mathrm{CHO}\left(1659 \mathrm{~cm}^{-1}\right)$ and 


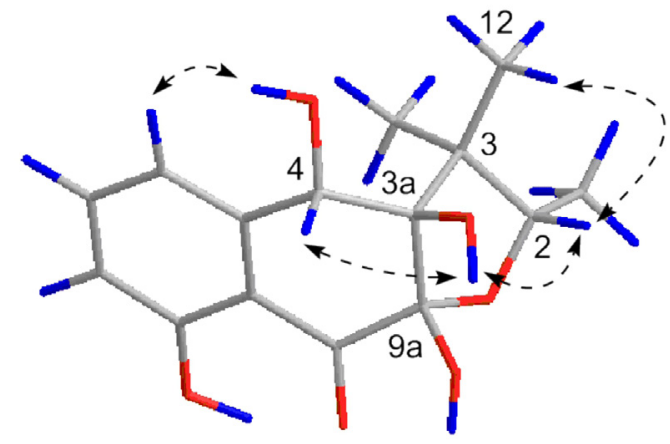

Figure 4. Key ROESY correlations of compound 2.

$\mathrm{Ph}\left(1583,1502\right.$ and $\left.1425 \mathrm{~cm}^{-1}\right)$ groups. The ${ }^{1} \mathrm{H}$ and ${ }^{13} \mathrm{C}$ NMR data of $\mathbf{3}$ showed high similarity with those of the known neolignan 8 isolated from Eucommia ulmoides Oliver (Figure S18 in the Supplementary Information (SI) section), ${ }^{18}$ which displays a negative optical rotation $\left[[\alpha]_{\mathrm{D}}^{25}-15.5(c 0.04, \mathrm{MeOH})\right]$. Since the optical rotation of $\mathbf{3}$ was positive, its $7 R, 8 \mathrm{~S}$ configuration was excluded. Nevertheless, due to the lack of available sample material, the $\mathrm{CD}$ spectrum of $\mathbf{3}$ could not be recorded, and the absolute configuration could not be assigned. The structure of $\mathbf{3}$ was further supported by HMBCs as shown in Figure 2. The coupling constant of $5.0 \mathrm{~Hz}$ between $\mathrm{H}-7$ and $\mathrm{H}-8$ suggested the two $\mathrm{H}$-atoms were in erythro-configuration. ${ }^{19}$ Accordingly, 3 was determined as 7' $E$-4,9-dihydroxy3,3',5'-trimethoxy-8,4'-oxyneolign-7'-en-9'-al.

Compounds 4-7 (Figure 1) were identified as (-)-8-hydroxy- $\alpha$-dunnione (4), ${ }^{8}$ digiferruginol (5), ${ }^{20}$ 2,5-dimethoxy-1,4-benzoquinone $(\mathbf{6})^{21}$ and $3 \alpha, 24-$ dihydroxy-olean-12-en-28-oic acid (scutellaric acid, 7), ${ }^{22,23}$ respectively, by comparison of their spectroscopic and physical data with those reported in the literature.

The inhibitory activity of compounds 1-7 against PRRSV was measured by the cytopathic effect (CPE) method. ${ }^{24}$ Digiferruginol (5) and scutellaric acid (7) showed weak effect on PRRSV with an $\mathrm{IC}_{50}$ (concentration of compound required for $50 \%$ inhibition) value of $80.5 \pm 16.9 \mu \mathrm{mol} \mathrm{L}^{-1}$ (selectivity index, SI > 19.9) and $43.2 \pm 7.4 \mu \mathrm{mol} \mathrm{L}^{-1}$ $(\mathrm{SI}=13.1)$, respectively, compared with tilmicosin phosphate $\left(\mathrm{IC}_{50}=225.1 \pm 27.4 \mu \mathrm{mol} \mathrm{L}-1, \mathrm{SI}=3.8\right)$ (Table 2). No significant inhibitory effects were observed for other compounds at a concentration of $200 \mu \mathrm{mol} \mathrm{L}{ }^{-1}$. Among the quinones (1, 2 and 4-6), only the active compound (5) belongs to the anthraquinone type. These results suggest that the carbon skeleton of anthraquinone might be necessary for the PRRSV-inhibitory activity. Previous studies find that digiferruginol (5) is also cytotoxic against human epidermoid carcinoma $\mathrm{KB}\left(\mathrm{IC}_{50}=9 \times 10^{-8} \mathrm{~g} \mathrm{~mL}^{-1}\right)$, Chinese hamster V-79 $\left(\mathrm{IC}_{50}=7.8 \times 10^{-6} \mathrm{~g} \mathrm{~mL}^{-1}\right)$, human hepatoma Hepa-3B $\left(\mathrm{IC}_{50}=3.85 \times 10^{-6} \mathrm{~g} \mathrm{~mL}^{-1}\right)$ and human cervical carcinoma HeLa $\left(\mathrm{IC}_{50}=2.45 \times 10^{-5} \mathrm{~g} \mathrm{~mL}^{-1}\right)$ cell lines. ${ }^{25-27}$ The inhibitory activity of the oleanane-type triterpene 7 against protein tyrosine phosphatase 1B (PTP1B) has been evaluated, but it was found to be inactive. ${ }^{28}$ The antiviral activity of compounds $\mathbf{5}$ and $\mathbf{7}$ against PRRSV is here reported for the first time.

Furthermore, by the real-time fluorescent quantitative reverse transcription-polymerase chain reaction (FQ RT-PCR), ${ }^{29-31}$ the relative expression ratio of non-strach polysaccharides NSP9 and open reading frame ORF7 genes of PRRSV was tested. As shown in Table 3 and Figure 5, NSP9 mRNA relative expression level was significantly reduced by compounds $\mathbf{5}$ and $\mathbf{7}$ at the concentrations of $50 \mu \mathrm{mol} \mathrm{L}-1$ or more $(P<0.001)$ in a dose-dependent manner. Also, ORF7 mRNA relative expression level was significantly reduced by compounds $\mathbf{5}$ and $\mathbf{7}$ at the concentration of $200 \mu \mathrm{mol} \mathrm{L}-1(P<0.001)$. The viral RNA-dependent RNA polymerase (RdRp; nsp9), a key enzyme for the RNA synthesis of PRRSV, is enc oded by the NSP9 gene. ${ }^{32}$ ORF7 encodes the nucleocapsid protein N which is the most abundant viral protein in virus-infected cells and essential during the assembly and disassembly of virions. ${ }^{33-35}$ The down regulation of NSP9 and ORF7 mRNA expression implied that the replication of PRRSV RNA and the assembly of the virons might be inhibited by the compounds.

\section{Experimental}

\section{General experimental procedures}

Melting points were determined using an X-4 melting point apparatus (Yingyu Yuhua Apparatus Factory, Gongyi, P. R. China), and were not corrected. Bruker SMART APEX-II and Bruker APEX DUO diffractometers using

Table 2. Inhibitory effects of 5 and $\mathbf{7}$ on PRRSV in Marc-145 cells

\begin{tabular}{lccc}
\hline Compound & $\mathrm{CC}_{50} /\left(\mu \mathrm{mol} \mathrm{L}^{-1}\right)$ & $\mathrm{IC}_{50} /\left(\mu \mathrm{mol} \mathrm{L}^{-1}\right)$ & $\mathrm{SI}$ \\
\hline Digiferruginol (5) & $>1600$ & $80.5 \pm 16.9$ & $>19.9$ \\
Scutellaric acid (7) & $566.6 \pm 2.6$ & $43.2 \pm 7.4$ & 13.1 \\
Tilmicosin phosphate (positive control) & $855.4 \pm 74.9$ & $225.1 \pm 27.4$ & 3.8 \\
\hline
\end{tabular}

$\mathrm{CC}_{50}$ : the median cytotoxic concentration; SI: selectivity index. 
Table 3. Inhibitory effects of $\mathbf{5}$ and $\mathbf{7}$ on mRNA expression of PRRSV ORF7 and NSP9 genes

\begin{tabular}{|c|c|c|c|c|}
\hline \multirow{2}{*}{ Concentration / $\left(\mathrm{mol} \mathrm{L}^{-1}\right)$} & \multicolumn{2}{|c|}{ NSP9 mRNA relative expression ratio } & \multicolumn{2}{|c|}{ ORF7 mRNA relative expression ratio } \\
\hline & compound 5 & Compound 7 & Compound $\mathbf{5}$ & Compound 7 \\
\hline 0 & $(1.0 \pm 2.0) \times 10^{-1}$ & $(1.0 \pm 2.0) \times 10^{-1}$ & $(1.0 \pm 2.3) \times 10^{-1}$ & $(1.0 \pm 2.3) \times 10^{-1}$ \\
\hline 25 & not tested & $1.5 \times 10^{-1} \pm 3.1 \times 10^{-2 \mathrm{a}}$ & not tested & $(1.3 \pm 1.3) \times 10^{-1}$ \\
\hline 50 & $2.4 \times 10^{-1} \pm 3.6 \times 10^{-2 a}$ & $6.1 \times 10^{-2} \pm 9.8 \times 10^{-3 \mathrm{a}}$ & $6.3 \pm 1.9$ & $(1.2 \pm 7.8) \times 10^{-2}$ \\
\hline 100 & $2.1 \times 10^{-1} \pm 2.2 \times 10^{-2 \mathrm{a}}$ & $6.0 \times 10^{-2} \pm 7.4 \times 10^{-3} \mathrm{a}$ & $7.6 \times 10^{-1} \pm 1.2 \times 10^{-1}$ & $3.8 \times 10^{-1} \pm 1.1 \times 10^{-1}$ \\
\hline 200 & $5.5 \times 10^{-3} \pm 4.8 \times 10^{-4 a}$ & $1.8 \times 10^{-3} \pm 1.8 \times 10^{-4 a}$ & $1.2 \times 10^{-2} \pm 1.0 \times 10^{-3 \mathrm{a}}$ & $6.0 \times 10^{-3} \pm 2.5 \times 10^{-3} \mathrm{a}$ \\
\hline 400 & $4.3 \times 10^{-5} \pm 3.8 \times 10^{-6 \mathrm{a}}$ & not tested & $1.5 \times 10^{-5} \pm 1.9 \times 10^{-6 \mathrm{a}}$ & not tested \\
\hline
\end{tabular}

${ }^{a} P<0.001$, as compared with the negative $\left(0 \mu \mathrm{mol} \mathrm{L}^{-1}\right)$ group.
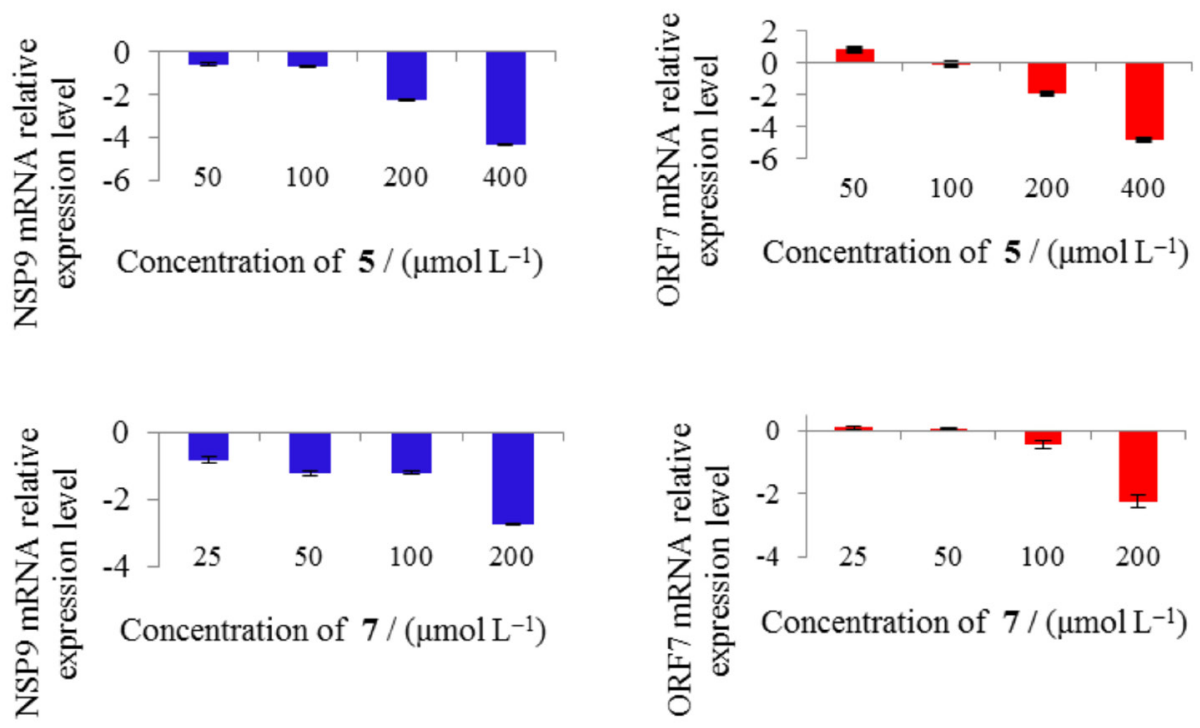

Figure 5. NSP9 (left) and ORF7 (right) mRNA relative expression level reduced by compounds $\mathbf{5}$ (upper) and 7 (lower).

graphite-monochromated $\mathrm{Cu} \mathrm{K}_{\alpha}$ radiations were employed for the intensity data collection, and the structures of compounds were solved by direct methods (SHELXS97). ${ }^{36}$ Optical rotations were determined on a JASCO DIP-370 automatic digital polarimeter. UV spectra were recorded on a Shimadzu double-beam 210A spectrometer. IR spectra were recorded on a Bio-Rad FTS-135 infrared spectrophotometer. Circular dichroism (CD) spectra were obtained using a JASCO J-715 spectropolarimeter (Japan Spectroscopic, Tokyo, Japan) in $\mathrm{CD}_{3} \mathrm{OD}$ solution. NMR spectra: Bruker AM-400, DRX-500 and Avance III-600 spectrometers with chemical shifts in ppm relative to tetramethylsilane (TMS) as an internal standard. ESIMS and HRESIMS were measured using an API QSTAR Pulsar 1 spectrometer. Column chromatography (CC): MCI gel (70-150 $\mu \mathrm{m}$; Mitsubishi Chemical Corporation), $\mathrm{C}_{18}$ silica gel (40-75 $\mu \mathrm{m}$; Fuji Silysia Chemical Ltd.), Sephadex LH-20 gel (40-70 $\mu \mathrm{m}$, GE Healthcare Bio-Xciences AB), silica gel $\mathrm{G}\left(\mathrm{SiO}_{2} ; 80-100\right.$ and 300-400 mesh; Qingdao Meigao Chemical Co.) and silica gel H (10-40 $\mu \mathrm{m})$. High- performance liquid chromatographic (HPLC) separations were performed using an Agilent 1200 series pump equipped with a diode array detector and a semi-preparative Zorbax SB-C ${ }_{18}(5 \mu \mathrm{m}, 9.4 \times 250 \mathrm{~mm})$ column. Thin layer chromatography (TLC) was conducted on precoated silica gel plates $\mathrm{GF}_{254}$ (Qingdao).

\section{Plant material}

The stems of Chirita longgangensis var. hongyao were collected from Jingxi County of Guangxi Zhuang Autonomous Region, P. R. China, in June 2010. The plant material was identified by Prof. Chun-Lin Long, and a voucher specimen (No. JX1001) was deposited at the Key Laboratory of Economic Plants and Biotechnology, Kunming Institute of Botany, Chinese Academy of Sciences.

\section{Extraction and isolation}

The air-dried stems of Chirita longgangensis var. hongyao $(4.5 \mathrm{~kg}$ ) were exhaustively extracted with $\mathrm{MeOH}$ 
(4, 3 and $3 \mathrm{~h}$, successively) at $70{ }^{\circ} \mathrm{C}$, and the solvent evaporated under reduced pressure. The $\mathrm{MeOH}$ extracts were evaporated under reduced pressure. The residue was suspended in $\mathrm{H}_{2} \mathrm{O}$ and extracted with petroleum ether and AcOEt. The AcOEt-soluble portion $(28 \mathrm{~g})$ was chromatographed by $\mathrm{MCI}$ gel $\left(\mathrm{MeOH} / \mathrm{H}_{2} \mathrm{O}, 90 \%\right)$ and $\mathrm{C}_{18}$ $\mathrm{MeOH} / \mathrm{H}_{2} \mathrm{O}\left(10\right.$ to $100 \%$, v/v) to give Fr. $\mathrm{A}\left(10 \% \mathrm{MeOH} / \mathrm{H}_{2} \mathrm{O}\right)$, Fr. B $\left(40 \% \mathrm{MeOH} / \mathrm{H}_{2} \mathrm{O}\right)$, Fr. C $\left(50 \% \mathrm{MeOH} / \mathrm{H}_{2} \mathrm{O}\right)$, Fr. D $\left(70 \% \mathrm{MeOH} / \mathrm{H}_{2} \mathrm{O}\right)$ and Fr. E $\left(80 \% \mathrm{MeOH} / \mathrm{H}_{2} \mathrm{O}\right)$. Fr. A was separated by Sephadex LH-20 (MeOH) to yield $6(5.3 \mathrm{mg})$. Fr. B was fractionated by Sephadex LH-20 $(\mathrm{MeOH})$ and silica gel $\left[\mathrm{CHCl}_{3}(\mathrm{v})\right]$ to give 3 (3.9 mg). Fr. C was fractionated by Sephadex LH-20 $(\mathrm{MeOH})$ and silica gel [ $\mathrm{CHCl}_{3} / \mathrm{MeOH}, 50: 1$ to $\left.40: 1(\mathrm{v} / \mathrm{v})\right]$ to give $\mathbf{1}(21.6 \mathrm{mg})$ and a mixture. The later was purified by semi-prep. HPLC $\left(\mathrm{MeOH} / \mathrm{H}_{2} \mathrm{O}, 40 \% ; t_{\mathrm{R}}=25.09 \mathrm{~min}\right)$ to yield $2(17.5 \mathrm{mg})$. Fr. D was separated by silica gel $\left[\mathrm{CHCl}_{3} / \mathrm{AcOEt}, 50: 1(\mathrm{v} / \mathrm{v})\right]$ to give $\mathbf{4}(3.9 \mathrm{mg})$ and $\mathbf{5}(9.3 \mathrm{mg})$. Fr. E was purified by recrystallisation $(\mathrm{MeOH})$ to give $\mathbf{7}(3.3 \mathrm{mg})$.

\section{Chiritalone A (1)}

Colorless crystals (from petroleum ether/ $\mathrm{CHCl}_{3}, 2: 1$ ); mp. $175-178^{\circ} \mathrm{C} ;[\alpha]_{\mathrm{D}}^{25}-3.1^{\circ}(c 0.28, \mathrm{MeOH}) ; \mathrm{UV}(\mathrm{MeOH})$ $\lambda_{\max } / \mathrm{nm}(\log \varepsilon) 359$ (2.81) and 240 (3.29); IR (KBr) $v_{\max } / \mathrm{cm}^{-1} 3521,3381,1685,1649,1576,1456,1225$, 1170, 984 and 856; $\mathrm{CD}(c 0.0125, \mathrm{MeOH}) 359(+0.37)$, $279(-1.05), 251(-0.16), 235(+2.22)$ and $211(+0.07)$ $\mathrm{nm} ;{ }^{1} \mathrm{H}$ and ${ }^{13} \mathrm{C}$ NMR data, see in Table 1; ESIMS $\mathrm{m} / z, 291$ $[\mathrm{M}-\mathrm{H}]^{-}, 327[\mathrm{M}+\mathrm{Cl}]^{-} ;$HRESIMS $\mathrm{m} / z$ (\%) 291.0865 $[\mathrm{M}]^{-}\left(\mathrm{C}_{15} \mathrm{H}_{16} \mathrm{O}_{6}\right.$, calcd. 291.0868).

\section{Crystal data for chiritalone A (1)}

$\mathrm{C}_{15} \mathrm{H}_{16} \mathrm{O}_{6}, \mathrm{MW}=292.28$, colorless prisms, size $0.41 \times 0.48 \times 0.60 \mathrm{~mm}^{3}$, monoclinic system, space group P2(1); $a=7.7816$ (2) $\AA, b=6.33270$ (10) $\AA$, $c=13.4381$ (3) $\AA, \alpha=\gamma=90^{\circ}, \beta=93.4560(10)^{\circ}$, $V=661.01(2) \AA^{3}, \mathrm{~T}=296(2) \mathrm{K}, Z=2, \rho_{\text {calcd }}=1.468 \mathrm{Mg} \mathrm{m}^{-3}$, $\mu\left(\mathrm{Cu} \mathrm{K}_{\alpha}\right)=0.963 \mathrm{~mm}^{-1}, F(000)=308,5415$ reflections in $h(-9 / 7), k(-7 / 6), l(-16 / 16)$, measured in the range $3.93^{\circ} \leq \theta \leq 68.13^{\circ}$, completeness $\theta_{\max }=92.5 \%, 1844$ independent reflections, $R_{\mathrm{int}}=0.0325,1840$ reflections with $|F|^{2} \geq 2 \sigma|F|^{2}, 196$ parameters, 1 restrains, GOF $=1.244$. Final $R$ indices $[\mathrm{I}>2 \operatorname{sigma}(\mathrm{I})]: R_{1}=0.0522, w R_{2}=0.1467$. $R$ indices (all data): $R_{1}=0.0523, w R_{2}=0.1471$. Flack parameter $0.1(2)$, largest difference peak and hole $=0.332$ and -0.437 e $\AA^{-3}$. The intensity data for $\mathbf{1}$ were collected on a Bruker APEX DUO diffractometer using graphite-monochromated $\mathrm{Cu} \mathrm{K}_{\alpha}$ radiation. The structure of 1 was solved by direct methods (SHELXS97), ${ }^{36}$ expanded using difference Fourier techniques, and refined by the program and full-matrix least-squares calculations.
The nonhydrogen atoms were refined anisotropically, and hydrogen atoms were fixed at calculated positions. Crystallographic data for the structure of $\mathbf{1}$ were deposited in the Cambridge Crystallographic Data Centre (deposition No. CCDC 852437).

\section{Chiritalone B (2)}

Colorless amorphous solid; $[\alpha]_{\mathrm{D}}^{25}+27.4^{\circ}(c) 0.08$, $\mathrm{MeOH}) ; \mathrm{UV}(\mathrm{MeOH}) \lambda_{\max } / \mathrm{nm}(\log \varepsilon) 342.6$ (2.84), 270.6 (3.17) and 215.6 (3.45); IR (KBr) $v_{\max } / \mathrm{cm}^{-1} 3441,1631$, 1511, 1459, 1127, 1091, 899 and 660; CD (c 0.0116, $\mathrm{MeOH}) 337(+1.17), 270(+3.05)$ and $217(-3.25) \mathrm{nm}$; ${ }^{1} \mathrm{H}$ and ${ }^{13} \mathrm{C}$ NMR data, see in Table 1; ESIMS $m / z, 293$ $[\mathrm{M}-\mathrm{H}]^{-}, 329[\mathrm{M}+\mathrm{Cl}]^{-}$; HRESIMS $\mathrm{m} / z$ (\%) 293.1024 $[\mathrm{M}]^{-}\left(\mathrm{C}_{15} \mathrm{H}_{18} \mathrm{O}_{6}\right.$, calcd. 293.1025).

7'E-4,9-Dihydroxy-3,3',5'-trimethoxy-8,4'-oxyneolign7'-en-9'-al (3)

Pale yellow oil; $[\alpha]_{\mathrm{D}}^{25}+6.1^{\circ}(c 0.49, \mathrm{MeOH})$; UV (MeOH) $\lambda_{\max } / \mathrm{nm}(\log \varepsilon) 320.0$ (3.37), 229.0 (3.56) and 202.5 (3.94); IR (KBr) $v_{\max } / \mathrm{cm}^{-1} 3441,1659,1624,1583$, 1502, 1425, 1243, 1224, 1033, 976 and 817; ${ }^{1} \mathrm{H}$ NMR (acetone) 9.56 (d, J 7.5 Hz, H-9'); 7.50 (d, J $15.7 \mathrm{~Hz}, \mathrm{H}-7^{\prime}$ ); 7.03 (br. s, H-2', 6'); 6.93 (br. s, H-2); 6.73 (d, J 7.6 Hz, H-6); 6.68 (dd, $J$ 15.7, 7.5 Hz, H-8'); 6.66 (d, J 7.6 Hz, H-5); 4.88 (d, J 5.0 Hz, H-7); 4.17 (br. s, H-8); 3.81 (s, MeO-3', 5'); 3.74-3.79 (m, $\mathrm{H}_{\mathrm{a}}-9$ ); 3.37 (br. d, $J 11.8 \mathrm{~Hz}$, $\left.\mathrm{H}_{\mathrm{b}}-9\right)$; ${ }^{13} \mathrm{C}$ NMR 194.1 (C-9'); 154.6 (C-3', 5'); 153.6 (C-7'); 148.0 (C-3); 146.6 (C-4); 139.3 (C-4'); 133.8(C-1); 131.1 (C-1'); 129.2 (C-8'); 120.1 (C-6); 115.3 (C-5); 110.9 (C-2); 107.0 (C-2', 6'); 88.1(C-8); 73.5 (C-7); 61.0 (C-9); 56.8 (C-3', 5'-OMe); 56.2 (C-3-OMe); ESIMS m/z 403 $[\mathrm{M}-\mathrm{H}]^{-}, 439[\mathrm{M}+\mathrm{Cl}]^{-}$; HRESIMS $\mathrm{m} / z$ (\%) 403.1390 $[\mathrm{M}]^{-}\left(\mathrm{C}_{21} \mathrm{H}_{24} \mathrm{O}_{8}\right.$, calcd. 403.1392).

\section{Cell culture and cytotoxicity assays}

Marc-145 cells (Cell Bank of the Chinese Academy of Sciences, Shanghai) were grown in monolayer in a $5 \%$ carbon dioxide and $95 \%$ atmosphere at $37{ }^{\circ} \mathrm{C}$, with Dulbecco's Modified Eagle Medium (DMEM; HyClone) containing $10 \%$ fetal bovine serum (HyClone), $100 \mathrm{U} \mathrm{mL}^{-1}$ of penicillin, and $1 \times 10^{-4} \mathrm{~g} \mathrm{~mL}^{-1}$ of streptomycin. Cytotoxicity assays were performed by the WST- 8 method, ${ }^{37,38}$ using Cell Counting Kit-8 (CCK-8; Beyotime Co.) according to the supplier recommendations. Briefly, cells were incubated in a 96-well microculture plate (Corning) in the absence or presence of twofold serial dilutions of compounds 1-7, and tilmicosin phosphate (Hubei Hengshuo Chemical Co. Ltd., China). After 3 days of culture, $10 \mu \mathrm{L}$ of CCK-8 solution were added, and the cells were incubated 
for $1.5 \mathrm{~h}$. The number of surviving cells was measured with a Bio-Tek ELx 800. ELISA microplate reader could show the detection wavelength of $450 \mathrm{~nm}\left(L_{1}\right)$ and the reference wavelength of $650 \mathrm{~nm}\left(L_{2}\right)$. The $50 \%$ cytotoxic concentration $\left(\mathrm{CC}_{50}\right)$ was obtained by nonlinear regression analysis of logistic curves (the value of $L_{1}-L_{2}$ to different concentrations of compounds).

\section{Cytopathic effect inhibition assay}

YN-1 strain of PRRSV was isolated from local pigs in Yunnan Province, P. R. China. ${ }^{39}$ The antiviral activity of tested compounds against viruses was measured by the CPE inhibition assay. ${ }^{24}$ Tissue culture medium infective dose $\left(\mathrm{TCID}_{50}\right)$ of 500 viral particles with twofold serial dilutions of the compounds were added to each test well, and the plates were reincubated for 4 days to allow development of a CPE if any. A non-infection control was made in the absence of natural products and tilmicosin phosphate was used for drug control. The concentration reducing CPE by $50 \%$ with respect to virus control was estimated from graphic plots and was defined $\mathrm{IC}_{50}$. The selectivity index was calculated from the ratio $\mathrm{CC}_{50} / \mathrm{IC}_{50}$.

\section{PRRSV mRNA expression inhibition assay}

The mRNA expression of PRRSV ORF7 and NSP9 genes was determined by real-time RT-PCR. ${ }^{29-31}$ Briefly, after 4 days of incubation, total virus RNA of both administration and control groups was isolated using RNAisoTM Plus (TaKaRa Biotechnology, Dalian, China), dissolved in $30 \mu \mathrm{L}$ of RNase-free water (TaKaRa), and then stored at $-80{ }^{\circ} \mathrm{C}$. According to the GenBank data base Accession No. PRU87392, primers were selected and designed from conserved regions based on the ORF7 and NSP9 sequences using Primer5.0 and Oligo6.0 software. A $330 \mathrm{bp}$ fragment of PRRSV ORF7 gene was amplified using the following primers: forward primer was 5'-AATGGCCAGCCAGTCAATCA-3' and reverse primer was 5'-TCATGCTGAGGGTGATGCTG-3'. A 162 bp fragment of PRRSV NSP9 gene was amplified using the following primers: forward primer was 5'-CACTAAAGAGGAAGTCGCACTCA-3' and reverse primer was 5'-GGTATGTCTCCAAACCTTGTATTCTG-3'. A 130 bp fragment of beta-actin gene was amplified using the following primers: forward primer was 5'-ATCCAGGCTGTGCTGTCC-3' and reverse primer was 5'-GAGGATCTTCATGAGGTAGTCG-3'.

cDNAs were synthesized using PrimeScript $\mathrm{RT}^{\circledR}$ Reagent Kit (TaKaRa) with $10 \mu \mathrm{L}$ of reaction mixtures containing $4.5 \mu \mathrm{L}$ of RNase Free $\mathrm{dH}_{2} \mathrm{O}, 2 \mu \mathrm{L}$ of
$5 \times$ PrimeScript Buffer, $0.5 \mu \mathrm{L}$ of PrimeScript RT Enzyme Mix I, $0.5 \mu \mathrm{L}$ of Random 6 mers $\left(100 \mu \mathrm{mol} \mathrm{L}^{-1}\right), 0.5 \mu \mathrm{L}$ of Oligo dT primer $(50 \mu \mathrm{mol} \mathrm{L}-1)$ and $2 \mu \mathrm{L}$ of total RNA. The reaction programme was as follows: $37^{\circ} \mathrm{C}$ for $15 \mathrm{~min}$, $85^{\circ} \mathrm{C}$ for $5 \mathrm{~s}$. The PCR mixture $(25 \mu \mathrm{L})$ contained $12.5 \mu \mathrm{L}$ of SYBR ${ }^{\circledR}$ Primix Ex Taq ${ }^{\mathrm{TM}}$ II (TaKaRa), $0.5 \mu \mathrm{L}$ of PCR forward primer $\left(10 \mu \mathrm{mol} \mathrm{L}^{-1}\right), 0.5 \mu \mathrm{L}$ of PCR reverse primer $\left(10 \mu \mathrm{mol} \mathrm{L}^{-1}\right), 9.5 \mu \mathrm{L}$ of $\mathrm{dH}_{2} \mathrm{O}$ and $2 \mu \mathrm{L}$ of cDNA. The reactions were carried out in an iQ5 real time PCR (Bio-Rad. Co. Ltd.). The reaction programme was as follows: one cycle at $95^{\circ} \mathrm{C}$ for $30 \mathrm{~s}$, followed by 40 cycles at $95^{\circ} \mathrm{C}$ for $5 \mathrm{~s}, 60^{\circ} \mathrm{C}$ for $30 \mathrm{~s}$.

\section{Statistical analyses}

All experiments were performed in three replications. Continuous variables, expressed as mean \pm standard deviation, were compared using one-way ANOVA (analysis of variance). Statistical analyses were conducted with SPSS 17.0 Statistics software.

\section{Conclusions}

In this research, seven compounds were isolated from the stems of $C$. longgangensis var. hongyao. Compounds $\mathbf{1}$ and $\mathbf{2}$ are new quinonoids, and $\mathbf{3}$ is a new neolignan. The inhibitory activity of all compounds against PRRSV was measured by the CPE method. Among the quinones (1, 2 and 4-6), only the active compound 5 belongs to the anthraquinone type. The results suggest that the carbon skeleton of anthraquinone might be necessary for the PRRSV-inhibitory activity.

\section{Supplementary Information}

Supplementary data (Figures S1-S18) are available free of charge at http://jbcs.sbq.org.br as PDF file.

\section{Acknowledgements}

This work was funded by the National Natural Science Foundation of China (Nos. 31070288, 20972166, 31160509 and 31161140345), Yunnan Provincial Program for Excellent Scientists (No. 2009CI125), the Key Research Direction Project of Knowledge Innovation Program for Chinese Academy of Sciences (No. KSCX2-EW-J-24), and the Ministry of Education of China through its 111 and 985 projects (Nos. B08044, MUC985-9 and MUC98506-01000101). We thank Dr. Xiao-Nian Li at the Kunming Institute of Botany who measured and elucidated the crystal structure. 


\section{References}

1. Tian, K. G.;Yu, X.L.;Zhao, T.Z.; Feng,Y.J .; Cao,Z.;Wang, C. B.; Hu, Y.; Chen, X. Z.; Hu, D. M.; Tian, X. S.; Liu, D.; Zhang, S.; Deng, X. Y.; Ding, Y. Q.; Yang, L.; Zhang, Y. X.; Xiao, H. X.; Qiao, M. M.; Wang, B.; Hou, L. L.; Wang, X. Y.; Yang, X. Y.; Kang, L. P.; Sun, M.; Jin, P.; Wang, S. J.; Kitamura, Y.; Yan, J. H.; Gao, G. F.; PLoS One 2007, 6, 1.

2. Karuppannan,A. K.; Wu, K. X.; Qiang, J.; Chu, J. J. H.; Kwang, J.; Antvirial Res. 2012, 94, 188.

3. Meng, X. J.; Vet. Microbiol. 2000, 74, 309.

4. Huang, Y. W.; Meng, X. J.; Virus Res. 2010, 154, 141.

5. Abad, M. J.; Bermejo, P.; Stud. Nat. Prod. Chem. 2005, 30, 303.

6. Inoue, K.; Ueda, S.; Nayeshiro, H.; Inouye, H.; Chem. Pharm. Bull. 1982, 30, 2265.

7. Thomson, R. H.; Pharm. World Sci. 1991, 13, 70.

8. Cai, X. H.; Luo, X. D.; Zhou, J.; Hao, X. J.; J. Nat. Prod. 2005, 68, 797.

9. Verdan, M. H.; Barison, A.; de Sá, E. L.; Salvador, M. J.; Poliquesi, C. B.; Eberlin, M. N.; Stefanello, M. É. A.; J. Nat. Prod. 2010, 73, 1434.

10. Xiao, X. B.; Lin, Y. X.; Xu, G. B.; Gong, X. B.; Gu, Y.; Tong, J. F.; Yang, J.; Helv. Chim. Acta 2011, 94, 404.

11. Wang, W. T.; Pan, K. Y.; Li, Z. Y.; Wetzman, A. L.; Skog, L. E.; Flora of China, vol. 18; Science Press: Beijing, P. R. China, 2010, p. 334.

12. China National Group Corporation of Traditional \& Herbal Medicine; The Chinese Traditional Medicine Resource Records; Science Press: Beijing, P. R. China, 1994, p. 1177.

13. Wang, M. Y.; Yang, L.; Tu, Y. Y.; China Journal of Chinese Materia Medica 2005, 30, 1921.

14. Wang, M. Y.; Yang, L.; Tu, Y. Y.; China Journal of Chinese Materia Medica 2006, 31, 307.

15. Wang, M. Y.; Fan, Y. J.; Zhang, J.; Gong, M. X.; China Journal of Chinese Materia Medica 2010, 35, 3188.

16. Cai, X. H.; Luo, X. D.; Zhou, J.; Hao, X. J.; J. Asian Nat. Prod. Res. 2006, 8. 351.

17. Wang, M. Y.; Gong M. X.; Zhang, D.; Yang, L.; Acta Pharmacol. Sin. 2011, 46, 179.

18. Chen, D. F.; Zhu, H. W.; Zhang, Y. Y.; Fudan University, Chin. Pat. 200710044099.5, 2007.

19. Li, S. F.; Di, Y. T.; Wang, Y. H.; Tan, C. J .; Fang, X.; Zhang, Y.; Zheng, Y. T.; Li, L.; He, H. P.; Li, S. L.; Hao, X. J.; Helv. Chim. Acta 2010, 93, 1795.
20. Kuo, S. C.; Chen, P. L.; Lee, S. W.; Chen, Z. T.; J. Chin. Chem. Soc. 1995, 42, 869.

21. Li, B.; Zhang, D. M.; Luo, Y. M.; Acta. Pharmacol. Sinica 2006, 41, 426.

22. Deepak, M.; Handa, S. S.; Phytochemistry 1998, 49, 269.

23. Morota, T.; Yang, C. X.; Sasaki, H.; Qin, W. Z.; Sugama, K.; Miao, K. L.; Yoshino, T.; Xu, L. H.; Maruno, M.; Yang, B. H.; Phytochemistry 1995, 39, 1153.

24. Ma, S. C.; He, Z. D.; Deng, X. L.; But, P. P. H.; Ooi, V. E. C.; Xu, H. X.; Lee, S. H. S.; Lee, S. F.; Chem. Pharm. Bull. 2001, 49, 1471.

25. Chang, P.; Lee, K. H.; J. Nat. Prod. 1985, 48, 948.

26. Itokawa, H.; Ibraheim, Z. Z.; Qiao, Y. F.; Takeya, K.; Chem. Pharm. Bull. 1993, 41, 1869.

27. Wu, T. S.; Lin, D. M.; Shi, L. S.; Damu, A. G.; Kuo, P. C.; Kuo, Y. H.; Chem. Pharm. Bull. 2003, 51, 948.

28. Thuong, P. T.; Lee, C. H.; Dao, T. T.; Nguyen, P. H.; Kim, W. G.; Lee, S. J.; Oh, W. K.; J. Nat. Prod. 2008, 71, 1775.

29. Pfaffl, M. W.; Nucleic Acids Res. 2001, 29, 2002.

30. Lurchachaiwong, W.; Payungporn, S.; Srisatidnarakul, U.; Mungkundar, C.; Theamboonlers, A.; Poovorawan, Y.; Lett. Appl. Microbiol. 2008, 46, 55.

31. Wang, Y. W.; Luo, R.; Fang, L. R.; Wang, D.; Bi, J.; Chen, H. C.; Xiao, S. B.; Mol. Immunol. 2011, 48, 586.

32. Fang, Y.; Snijder, E. J.; Virus Res. 2010, 154, 61.

33. Snijder, E. J.; Meulenberg, J. J. M.; J. Gen. Virol. 1998, 79, 961.

34. He, Y. X.; Hua, R. H.; Zhou, Y. J.; Qiu, H. J.; Tong, G. Z.; Antiviral Res. 2007, 74, 83.

35. Hao, X. F.; Lu, Z. J.; Kuang, W. D.; Sun, P.; Fu, Y.; Wu, L.; Zhao, Q.; Bao, H. F.; Fu, Y. F.; Cao,Y. M.; Li, P. H.; Bai, X. W.; Li, D.; Liu, Z. X.; J. Virol. 2011, 8, 1.

36. Sheldrick, G. M.; SHELXS-97, Program for Crystal Structure Solution; University of Göttingen: Göttingen, Germany, 1997.

37. Ishiyama, M.; Shiga, M.; Sasamoto, K.; Mizoguchi, M.; He, P. G.; Chem. Pharm. Bull. 1993, 41, 1118.

38. Tominaga, H.; Ishiyama, M.; Ohseto, F.; Sasamoto, K.; Hamamoto, T.; Suzuki, K.; Watanabe, M.; Anal. Commun. 1999, 36, 47.

39. Duan, B. F.; Shen, Y. P.; Yang, G. S.; Zhang, Y. F.; Wu, J. M.; Duan, G.; Yin, G. F.; Prog. Vet. Med. 2010, 31, 11.

Submitted: June 15, 2012 Published online: October 30, 2012 